\title{
Response of Rats to Repeated Oral Administration of Endosulfan*
}

\author{
T.S.S. DIKSHITH ${ }^{* *}$, R.B. RAIZADA, M.K. SRIVASTAVA and \\ B.S. KAPHALIA
}

Industrial Toxicology Research Centre,

Post Box No. 80, Mahatma Gandhi Marg, Lucknow-226 001, India

(Received April 12, 1984 and in revised form July 6, 1984)

\begin{abstract}
Male and female albino rats given different oral doses $(0.75,2.5,5.0$ and $0.25,0.75,1.5 \mathrm{mg} / \mathrm{kg} / \mathrm{D})$ of endosulfan respectively for a period of 30 days elicited signs of toxicity such as hyperexcitability, tremor, dyspnea and salivation for a brief period. At the tested dose levels, endosulfan produced no significant change in the organ body weight ratio, biochemical, histological, haematological and fertility indices. Residue analysis using GLC techniques of different organs revealed a higher level of $\alpha$ isomer in the fatty tissue of male and female rats, than in other organs. There was no significant accumulation of the $\alpha$ and $\beta$ isomers of endosulfan in the vital organs inspite of repeated exposure which seems to be the reason for the absence of a severe toxicological response in the rats. The lower doses of endosulfan, however, showed none of the toxicological effects in male $(0.75$ and $2.5 \mathrm{mg} / \mathrm{kg} / \mathrm{D})$ and female $(0.25$ and $0.75 \mathrm{mg} / \mathrm{kg} / \mathrm{D})$ rats.
\end{abstract}

Key words: Endosulfan-Oral toxicity-Male and female rat-Fertility-Residue

\section{INTRODUCTION}

Large scale manufacture and tremendous utilization of a variety of pesticides and their formulations for the control of crop pests and vectors of communicable diseases has caused global concern. ${ }^{1-3)}$ Endosulfan a nonsystemic contact organochlorinated insecticide and acaricide is used extensively for pest control. In India about 1000 metric tons of endosulfan and its formulations have been in use. ${ }^{4,5)}$ Reports are available on the physical, chemical as well as toxicological effects of endosulfan in animals. ${ }^{6-11)}$ In view of its large scale use there is an urgent need to gather more toxicological data on the cummulative effects of endosulfan in mammals which could be utilized for a meaningful extrapolation of poisoning in humans. This has, therefore, prompted us to investigate the cummulative effects

* Endsosulfan -6, 7, 8, 9, 10, 10a hexachloro, 1, 5, 5a, 6, 9, 9a-hexahydro, 6, 9-methano-

2, 4, 3-benzodioxathiepin 3-oxide

** Reprint request. 
of endosulfan using various parameters such as clinical signs of toxicity, morphological, biochemical, haematological, fertility changes and residues in male and female albino rats.

The lower levels of endosulfan could not alter any of the toxicological parameters and the changes were comparable with those of normal animals. The present report, hence, restricts only to the observations made in rats given highest oral doses of endosulfan.

\section{Materials AND Methods}

A total number of 69 male and female albino rats of 12 week old ( $R$. norvigicus, Wistar strain) of Industrial Toxicology Research Centre's colony and maintained in air conditoned room $\left(75 \pm 2^{\circ} \mathrm{F}\right)$ of animal house were used in the study. The animals were maintained on rat pellet diet (Hindustan Lever Animal Feed, India) and water ad libitum. The animals were acclimatized to light and temperature of the animal room before medication.

\section{Chemical:}

Endosulfan technical (purity 98\%) has the structural formula shown in Fig. 1 and is a mixture of two stero isomers-alpha endosulfan, endosulfan (I) and beta endosulfan, endosulfan (II). The proportion of the two isomers in the endosulfan samples used here is $65.32 \%$ and $33.68 \%$ respectively. Earlier studies ${ }^{12,13)}$ have shown that acute toxicity of endosulfan technical after single oral doses with peanut oil as vehicle was $23.82 \mathrm{mg} / \mathrm{kg}$ in male and $13.65 \mathrm{mg} / \mathrm{kg}$ in female albino rat.

\section{Treatment:}

Based on the above information different test doses of endosulfan $(0,0.25$, $0.75,1.5,2.5$ and $5.0 \mathrm{mg} / \mathrm{kg} / \mathrm{D}$ ) were administered orally for a period of 30 days with peanut oil as vehicle to male and female albino rats. On completion of medication control and treated animals were grouped for different studies and

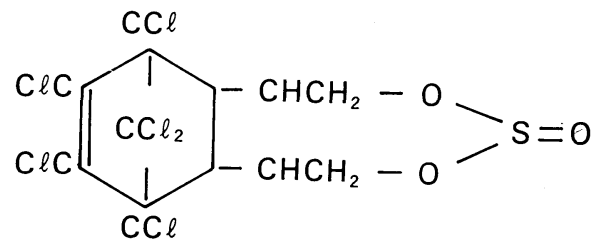

Fig. 1. Structural formula of endosulfan$6,7,8,9,10,10 \mathrm{a}$-hexachloro-1, 5, 5a, 6, 9, 9a-hexahydro, 6, 9-methano-2, 4, 3-benzodioxathiepin-3-oxide. 
killed by decapitation. The treatment schedule has been shown in Table 1 . Blood was collected directly from jugular vein into tubes with oxalates for biochemical, haematological and residue assays.

Organ/body weight ratio:

Body weight of each animal was recorded before decapitation. At necropsy liver, kidney, adrenal, brain, spleen, testes, epididymis, ovary, uterus, cervix and vagina were removed quickly and weighed and the organ/body weight ratio was calculated.

Histopathological studies:

Sections of liver, kidney, brain, spleen, testes, epididymis uterus and vagina and whole of the adrenal, ovary and cervix were fixed in formal saline solution. After routine processing of each tissue paraffin sections were cut at $6 /$ um thickness and stained in haematoxylin-eosin for microscopic observations.

\section{Biochemical studies:}

Freshly removed liver was washed free from extraneous material using chilled saline and homogenized in $0.25 \mathrm{M}$ ice cold sucrose solution $10 \% \mathrm{w} / \mathrm{v}$ in a Potter Elvehjem type homogenizer. The homogenate was centrifuged at $700 \times \mathrm{g}$ for $10 \mathrm{~min}$ to remove cell debris. The supernatant of liver and blood serum were used for enzyme and protein estimations.

The activity of glutamic oxaloacetic transaminase (GOT, EC. 2.6.1.1.), glutamic pyruvic transaminase (GPT, EC. 2.6.1.2.) and alkaline phosphatase (Orthophosphoric monoester phosphohydrolase EC. 3.1.3.1.) was assayed according to the method of Wootton. ${ }^{14)}$ Protein was estimated by the procedure of Lowry et al. ${ }^{15)}$ Blood sugar was assayed as per the method of Nelson and Somogyi. ${ }^{16)}$

\section{Haematological studies:}

The RBC and WBC counts were determined according to the method of Wintrobe and Landsberg, ${ }^{17)}$ whereas the procedure of Kolmer et al. ${ }^{18)}$ was adopted to measure $\mathrm{Hb}$ and DLC.

Residue analysis:

Level of endosulfan in brain, fatty tissue, liver, kidney and serum of treated rats was analysed using varian Aerograph series 2400 gas-liquid chromatograph with $\mathrm{H}^{3}$ electron capture detecting system. The method of analysis is similar to the one reported earlier. ${ }^{7)}$

Fertility study:

Endosulfan treated and control animals were mated as indicated in Tables 1 and 6. The vaginal smear of each female rat was examined daily for the presence of spermatozoa. When positive the females were separated and allowed to complete 
Table 1. Treatment schedule in male and female rats after oral administration of endosulfan technical for 30 days

\begin{tabular}{|c|c|c|c|c|c|}
\hline \multirow[b]{2}{*}{ Treatment } & \multirow[b]{2}{*}{$\operatorname{Sex}$} & \multirow[b]{2}{*}{ Total } & \multicolumn{3}{|c|}{ No. of animals } \\
\hline & & & $\begin{array}{l}\text { Biochemical, residual } \\
\text { and pathological } \\
\text { studies }\end{array}$ & $\begin{array}{l}\text { Fertility } \\
\text { studies }\end{array}$ & $\begin{array}{l}\text { Group for mating } \\
\text { (1 male and } \\
2 \text { female) }\end{array}$ \\
\hline $\begin{array}{l}\text { Control } \\
\text { (Peanut oil }\end{array}$ & Male & 16 & 6 & $5^{d}, 5^{e}$ & $a \times b$ \\
\hline $0.5 \mathrm{ml} / \mathrm{kg} / \mathrm{d})$ & Female & 26 & 6 & $10^{\mathrm{b}}, 10^{\mathrm{f}}$ & $\mathrm{c} \times \mathrm{d}$ \\
\hline $\begin{array}{l}\text { Endosulfan } \\
(5.0 \mathrm{mg} / \mathrm{kg} / \mathrm{d})\end{array}$ & Male & 11 & 6 & $5^{a}$ & $e \times f$ \\
\hline$(1.5 \mathrm{mg} / \mathrm{kg} / \mathrm{d})$ & Female & 16 & 6 & $10^{\mathrm{c}}$ & \\
\hline
\end{tabular}

the full term of pregnancy, number of pregnancy, number and weight of pups and also their mortality rate were recorded.

Statistical significance between experimental and control values were calculated according to Fisher's student 't' test. ${ }^{19}$ )

\section{RESULTS}

Signs of toxicity:

Male and female rats administered with endosulfan at the test dose levels showed signs of hyperexcitation, tremor, dyspnea and salivation for a very brief period which however disappeared after 3-4 days.

Organ/body weight ratio:

Change in the body weight of the treated male and female rats in comparison to controls was not significant. Male rats exposed to endosulfan for 30 days revealed a marginal increase in the weight ratio of liver, kidney, epididymis $(\mathbf{P}<0.05)$ and testes $(\mathbf{P}<0.01)$. While female rats showed a slight fall in the weight ratio of kidney $(\mathrm{P}<0.01)$ (Table 2$)$.

\section{Histopathological changes:}

There were no gross abnormalities in the vital organs of endosulfan treated animals. Microscopic examination of liver, kidney, testes, epididymis and brain did not show any noticeable morphological change.

\section{Biochemical changes:}

The activity of GOT, GPT, alkaline phosphatase and protein are shown in Table 3. An increase $(P<0.01-P<0.02)$ in the activity of liver alkaline phosphatase was observed in male and female rats. Serum alkaline phosphatase increased $(\mathrm{P}<0.02)$ and decreased $(\mathrm{P}<0.01)$ in male and female rats respectively. 
Table 2. Organ body weight ratio of rats after oral administration of endosulfan technical for 30 days

\begin{tabular}{|c|c|c|c|c|}
\hline \multirow[b]{2}{*}{ Treatment } & \multicolumn{2}{|c|}{ Male } & \multicolumn{2}{|c|}{ Female } \\
\hline & $\begin{array}{c}\text { Control } \\
\text { (Peanut oil) }\end{array}$ & $\begin{array}{c}\text { Endosulfan } \\
(5.0 \mathrm{mg} / \mathrm{kg} / \mathrm{d})\end{array}$ & $\begin{array}{c}\text { Control } \\
\text { (Peanut oil) }\end{array}$ & $\begin{array}{l}\text { Endosulfan } \\
(1.5 \mathrm{mg} / \mathrm{kg} / \mathrm{d})\end{array}$ \\
\hline \multicolumn{5}{|l|}{ Body weight } \\
\hline Initial body weight & 84 & 87 & 85 & 83 \\
\hline Final body weight & 237 & 236 & 234 & 225 \\
\hline Liver & $2.87 \pm 0.10$ & $3.46 \pm 0.18^{\mathrm{b}}$ & $3.08 \pm 0.13$ & $3.05 \pm 0.19$ \\
\hline Kidney & $0.57 \pm 0.02$ & $0.65 \pm 0.03^{b}$ & $0.65 \pm 0.01$ & $0.56 \pm 0.02^{\mathrm{a}}$ \\
\hline Adrenal & $0.008 \pm 0.001$ & $0.008 \pm 0.0003$ & $0.02 \pm 0.002$ & $0.02 \pm 0.002$ \\
\hline Brain & $0.52 \pm 0.03$ & $0.57 \pm 0.014$ & $0.77 \pm 0.02$ & $0.72 \pm 0.02$ \\
\hline Spleen & $0.27 \pm 0.02$ & $0.28 \pm 0.05$ & $0.31 \pm 0.02$ & $0.29 \pm 0.07$ \\
\hline Testes/ovary & $0.45 \pm 0.03$ & $0.99 \pm 0.02^{b}$ & $0.03 \pm 0.005$ & $0.03 \pm 0.002$ \\
\hline Epididymis/uterus & $0.23 \pm 0.04$ & $0.34 \pm 0.015$ & $0.19 \pm 0.02$ & $0.17 \pm 0.006$ \\
\hline Cervix & - & - & $0.029 \pm 0.005$ & $0.02 \pm 0.002$ \\
\hline Vagina & - & - & $0.053 \pm 0.005$ & $0.05 \pm 0.003$ \\
\hline
\end{tabular}

Values represent the mean $\pm \mathrm{SE}$ of 6 animals

a $\mathrm{p}<0.01 ;$ b $\mathrm{p}<0.05$

Table 3. Biochemical changes in male and female rats after oral administration of endosulfan technical for 30 days

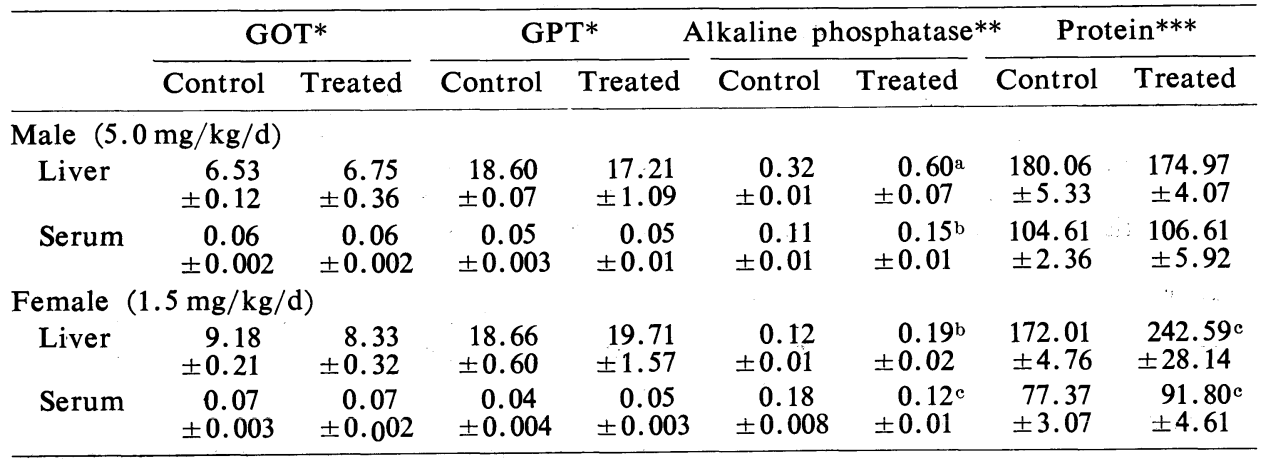

Values represent the mean $\pm S E$ of 6 animals

a $\mathrm{p}<0.01 ;{ }^{\mathrm{b}} \mathrm{p}<0.02 ;{ }^{\mathrm{c}} \mathrm{p}<0.05$

* Activity expressed in $/ \mu$ mole pyruvate liberated $/ \mathrm{g}$ tissue or $/ \mathrm{m} l \mathrm{serum} / \mathrm{min}$.

** Activity expressed in $/ \mu$ mole phenol liberated $/ \mathrm{g}$ tissue or $/ \mathrm{m} l$ serum $/ \mathrm{min}$.

*** Activity expressed in $\mathrm{mg} / \mathrm{g}$ tissue or $/ \mathrm{m} l$ serum.

Except for a marginal increase $(\mathrm{P}<0.05)$ of liver and serum protein, no other biochemical changes were observed in rats.

\section{Haematological changes:}

No significant haematological changes were observed in male and female rats exposed to endosulfan except a slight increase in $\mathrm{RBC}(\mathrm{P}<0.02)$ and neutrophil $(\mathrm{P}<0.05)$ counts in male rats (Table 4$)$. 
Table 4. Hematological observations in male and female rats after oral administration of endosulfan technical for $\mathbf{3 0}$ days.

\begin{tabular}{|c|c|c|c|c|c|c|c|c|}
\hline \multirow{2}{*}{ Treatment } & \multirow{2}{*}{$\begin{array}{c}\text { RBC } \\
\left(10^{6} /\right. \\
\left.\mathrm{mm}^{3}\right)\end{array}$} & \multirow{2}{*}{$\begin{array}{c}\text { WBC } \\
\left(10^{3} /\right. \\
\left.\mathrm{mm}^{3}\right)\end{array}$} & \multirow{2}{*}{$\begin{array}{l}\mathrm{Hb} \\
(\mathrm{g} / \\
100 \mathrm{~m} l)\end{array}$} & \multicolumn{4}{|c|}{ DLC (\%) } & \multirow{2}{*}{$\begin{array}{l}\underset{(\mathrm{mg} g /}{\text { Sugar }} \\
100 \mathrm{~m} l)\end{array}$} \\
\hline & & & & L & $\mathbf{N}$ & $\mathbf{M}$ & $\mathrm{E}$ & \\
\hline \multicolumn{9}{|l|}{ Male } \\
\hline $\begin{array}{l}\text { Control } \\
\text { (Peanut oil) }\end{array}$ & $\begin{array}{r}10.42 \\
\pm 0.37\end{array}$ & $\begin{array}{r}6.58 \\
\pm 0.96\end{array}$ & $\begin{array}{r}16.9 \\
\pm 0.4\end{array}$ & $\begin{array}{r}72.75 \\
\pm 1.03\end{array}$ & $\begin{array}{c}26.0 \\
\pm 0.81\end{array}$ & $\begin{array}{r}1.25 \\
\pm 0.26\end{array}$ & 一 & $\begin{array}{r}81.03 \\
\pm 4.26\end{array}$ \\
\hline $\begin{array}{l}\text { Endosulfan } \\
(5 \mathrm{mg} / \mathrm{kg} / \mathrm{d})\end{array}$ & $\begin{array}{l}11.67^{\mathrm{b}} \\
\pm 0.26\end{array}$ & $\begin{array}{r}8.06 \\
\pm 2.71\end{array}$ & $\begin{array}{r}17.46 \\
\pm 0.88\end{array}$ & $\begin{array}{r}70.25 \\
\pm 0.86\end{array}$ & $\begin{array}{l}29.25^{b} \\
\pm 0.94\end{array}$ & $\begin{array}{r}0.5 \\
\pm 0.3\end{array}$ & - & $\begin{array}{r}88.07 \\
\pm 2.02\end{array}$ \\
\hline \multicolumn{9}{|l|}{ Female } \\
\hline $\begin{array}{l}\text { Control } \\
\text { (Peanut oil) }\end{array}$ & $\begin{array}{r}12.14 \\
\pm 0.31\end{array}$ & $\begin{aligned} & 9.4 \\
\pm & 0.45\end{aligned}$ & $\begin{array}{r}15.65 \\
\pm 0.33\end{array}$ & $\begin{array}{l}81.0 \\
\pm 1.29\end{array}$ & $\begin{array}{r}16.75 \\
\pm 0.85\end{array}$ & $\begin{array}{l}1.5 \\
\pm 0.28\end{array}$ & $\begin{aligned} & 0.75^{\mathrm{a}} \\
\pm & 0.25\end{aligned}$ & $\begin{array}{r}96.15 \\
\pm 4.66\end{array}$ \\
\hline $\begin{array}{l}\text { Endosulfan } \\
(1.5 \mathrm{mg} / \mathrm{kg} / \mathrm{d})\end{array}$ & $\begin{array}{r}13.57 \\
\pm 0.77\end{array}$ & $\begin{array}{r}6.56 \\
\pm 0.47\end{array}$ & $\begin{array}{r}17.25 \\
\pm 0.29\end{array}$ & $\begin{array}{r}77.25 \\
\pm 1.79\end{array}$ & $\begin{array}{r}20.25 \\
\pm 1.11\end{array}$ & $\begin{aligned} & 1.5 \\
\pm & 2.89\end{aligned}$ & $\begin{array}{r}1.25 \\
\pm 0.63\end{array}$ & $\begin{array}{l}72.35^{\mathrm{b}} \\
\pm 7.13\end{array}$ \\
\hline
\end{tabular}

Values represent mean $\pm \mathrm{SE}$ of 6 animals.

RBC: red blood cells; WBC: white blood cells; Hb: Heamoglobin; L: lymphocytes; $\mathrm{N}$ : neutrophils; $\mathrm{M}$ : monocytes; $\mathrm{E}$ : esosinophils.

a $\mathrm{p}<0.01 ; \mathrm{b} \mathrm{p}<0.05$

Table 5. Levels of $\alpha$ and $\beta$ isomers (ppm) in tissues of rats given endosulfan technical for 30 days

\begin{tabular}{|c|c|c|c|c|c|c|}
\hline \multirow[b]{2}{*}{ Tissue } & \multicolumn{3}{|c|}{ Male } & \multicolumn{3}{|c|}{ Female } \\
\hline & $\alpha$ Isomer & $\beta$ Isomer & $\begin{array}{c}\text { Total } \\
\text { endosulfan }\end{array}$ & $\alpha$ Isomer & $\beta$ Isomer & $\begin{array}{c}\text { Total } \\
\text { endosulfan }\end{array}$ \\
\hline Blood serum & $\begin{array}{r}0.0267 \\
\pm 0.0008\end{array}$ & ND & $\begin{aligned} & 0.0267^{\mathrm{a}} \\
\pm & 0.0008\end{aligned}$ & $\begin{array}{r}0.0151 \\
\pm 0.0024\end{array}$ & ND & $\begin{aligned} & 0.0151^{\mathrm{b}} \\
\pm & 0.0024\end{aligned}$ \\
\hline Fatty tissue & $\begin{array}{r}0.2891 \\
\pm 0.0073\end{array}$ & ND & $\begin{array}{c}0.2891^{\mathrm{a}} \\
\pm 0.0073^{2}\end{array}$ & $\begin{array}{c}0.5471 \\
\pm 0.01214\end{array}$ & $\begin{array}{r}0.1794 \\
\pm 0.0099\end{array}$ & $\begin{aligned} & 0.7265^{\mathrm{a}} \\
\pm & 0.0313\end{aligned}$ \\
\hline Liver & $\begin{array}{r}0.1118 \\
\pm 0.0206\end{array}$ & $\begin{array}{r}0.0241 \\
\pm 0.0033\end{array}$ & $\begin{aligned} & 0.1359 \mathrm{~b} \\
\pm & 0.0239\end{aligned}$ & $\begin{aligned} & 0.0836 \\
\pm & 0.019\end{aligned}$ & $\begin{array}{r}0.0263 \\
\pm 0.0053\end{array}$ & $\begin{aligned} & 0.1099^{\mathrm{b}} \\
\pm & 0.0243\end{aligned}$ \\
\hline Kidney & $\begin{array}{r}0.1195 \\
\pm 0.0208\end{array}$ & $\begin{array}{r}0.0261 \\
\pm 0.0061\end{array}$ & $\begin{array}{r}0.1456 \\
\pm 0.0269\end{array}$ & $\begin{array}{r}0.0594 \\
\pm 0.0084\end{array}$ & ND & $\begin{aligned} & 0.0594^{\mathrm{b}} \\
\pm & 0.0084^{4}\end{aligned}$ \\
\hline Brain & ND & ND & ND & ND & ND & ND \\
\hline
\end{tabular}

Peanut oil treated animals (control) did not show any peak for endosulfan ( $\alpha$ or $\beta$ ). Values represent the mean $\pm \mathrm{SE}$ of 6 animals.

Significantly different from control: a $\mathrm{p}<0.001 ; \mathrm{b} \mathrm{p}<0.01$.

\section{Residue analysis:}

Levels of $\alpha$ and $\beta$ isomers of endosulfan in brain, fatty tissue, liver kidney and serum of male and female rats are shown in Table 5 and Figure 2. Fatty tissue contained the highest level of the $\alpha$ isomer in male and female rats. The order of residue level of $\alpha$ isomer in rats is as under. Male: fatty tissue $>$ kidney $>$ liver $>$ serum; Female: fatty tissue $>$ liver $>$ kidney $>$ serum. The presence of $\alpha$ or $\beta$ isomers in the brain of experimental rats was non detectable. The residue level in fatty tissue was much higher in female $(0.73 \mathrm{ppm})$ than in male $(0.29 \mathrm{ppm})$ in contrast to total administered doses. 


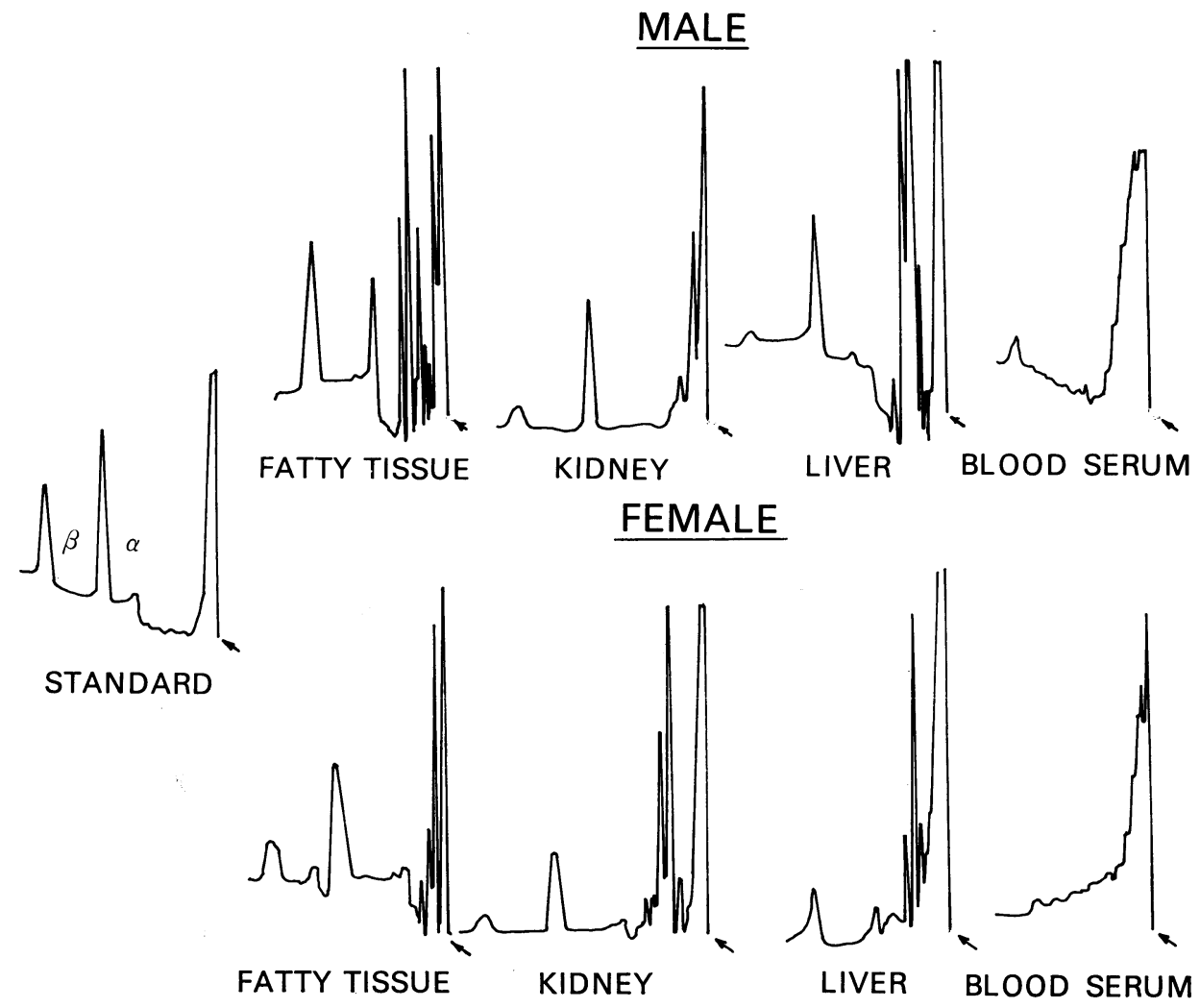

Fig. 2. Electron capture gas chromatogram of extractives of male and female rats after oral administration of endosulfan 5.0 and $1.5 \mathrm{mg} / \mathrm{kg} / \mathrm{D}$ respectively for 30 days.

Detector temp. $200^{\circ} \mathrm{C}$; Injector temp. $190^{\circ} \mathrm{C}$; Column temp. $180^{\circ} \mathrm{C}$; Flow rate $\mathrm{N}_{2} 40 \mathrm{ml} / \mathrm{min}$; Chart speed $0.5 \mathrm{~cm} / \mathrm{min}$; Attenuation $2 \times 10^{-9} \mathrm{~A}$.

Table 6. Fertility effects in rats given endosulfan technical for 30 days

\begin{tabular}{llrrr}
\hline \multirow{2}{*}{ Parameters } & \multicolumn{3}{c}{ Group for mating } \\
\cline { 3 - 5 } & $\mathrm{a} \times \mathrm{b}$ & $\mathrm{c} \times \mathrm{d}$ & $\mathrm{e} \times \mathrm{f}$ \\
\hline 1. Female fertility index* & 90 & 100 & 100 \\
2. Total No. of pups born & 85 & 90 & 110 \\
3. Average weight of each pup (g) & 5.5 & 5.5 & 6.0 \\
4. Survival index** of (10 days) & 89.4 & 75.5 & 95.5 \\
\hline
\end{tabular}

$$
\begin{aligned}
& *=\frac{\text { No. of females conceived }}{\text { No. of females exposed to fertile male }} \times 100 \\
& * *=\frac{\text { No. of pups viable at lactation day } 10}{\text { No of viable pups born }} \times 100
\end{aligned}
$$

Fertility study:

Evaluation of differnt parameters of fertility study of endosulfan treated rats 
did not suggest any type of ill effects. The number of pups, the average weight of each pup and also their survival until day 10 of parturition was comparable with those of control animals (Table 6).

\section{Discussion}

The present study as an extension of the earlier work ${ }^{7-9,20)}$ is aimed at pooling more data on the effect of repeated exposure of endosulfan in male and female rats. While the animals initially exhibited clinical signs of pesticide intoxication, they soon recovered without further toxicity. Repeated exposure of endosulfan for a period of 26 through 104 weeks caused death in animals and produced damage in liver, kidney and testes of rats and mice. ${ }^{10,25)}$

Comparison of various facets of study like organ/body weight ratio, biochemical, histological, haematological, fertility and residue analysis of endosulfan treated rats implied no severity to animals at the tested doses and period of exposure. It is important to note here that the response of the male and female animal is related with the dose of the test chemical which interacts with the molecular/ receptor site in the organism, i.e., the initiation and perpetuation of the toxic response in the organism has a relationship with the bioavailability and concentration of the test chemical at the reactive site ${ }^{21,22}$ and also the duration it remains. ${ }^{23)}$ Earlier it has been shown that endosulfan undergoes metabolic changes in mammals as endosulfan diol and other hydrophylic metabolites and rapidly excreted from the body. ${ }^{6,24)}$ Endosulfan sulphate has been detected in animal tissues for a very brief period only. Thus endosulfan has not shown any kind of bioaccumulation or carcinogenic potential. ${ }^{24,25)}$ It is of interest to note that the accumulation pattern of $\alpha$ and $\beta$ isomers differed not only between male and female rats but among different vital organs. As expected the fatty tissue in male and female rats accumulated the highest of the $\alpha$ isomer followed by other tissues. Further the residue build up in male was much lower as compared to female rat. In other words, the elimination of this pesticide was much quicker in male than in female rat. This partially explains the reason for the higher $L_{50}$ value of endosulfan in male than in female rat, besides suggesting the differential pattern of metabolism of endosulfan in male and female rat. Perhaps it is these factors and the mechanism of homeostasis has made the animals to withstand the toxicological effect of endosulfan inspite of repeated oral administration.

\section{ACKNOWLEDGEMENT}

Grateful thanks are due to Dr. G. B. Singh for his keen interest and encouragement. Thanks are also due to R. A. Kaushal, R. P. Singh and K. P. Gupta for technical assistance. 


\section{REFERENCES}

1) Mrak, E. M. (1969). Report of Secretary's Commission on Pesticides and Their Relationship to Environmental Health, p. 677, U.S. Dept. Health. Education and Welfare, Washington, D.C.

2) Miles, J. R., Harris, C. R. and Moy, P. (1978). Insecticide residues in water, sediment, and fish of the drainage system of the Holl and Marsh, Ontario, Canada. 1972-1975, J. Econ. Entomol., 71, 125-131.

3) Milius, P. (1976). A pesticide that cripples mind and body, Honolulu star-Bulletin and Advertiser, December 6, G. 23.

4) Ministry of Agriculture \& Irrigation, Govt. of India (1978). Central Insecticide Board, Report of the Sub-committee on Pesticide Toxicology.

5) Ministry of Petroleum Chemicals \& Fertilizers, Govt. of India (1979). Report of the Working Group on Pesticide, Industry for the Plan (1978-79 to 1983-84).

6) Maier-Bode, H. (1968). Properties, effect, residue and analysis of the insecticide endosulfan, Residue Rev., 22, 1.

7) Nath, G., Datta, K. K., Dikshith, T. S. S., Tandon, S. K. and Pandya, K. P. (1978). Interaction of endosulfan and metapa in rats, Toxicology, 11, 385.

8) Dikshith, T. S. S., Nath, G. and Datta, K. K. (1978). Combined cytogenetic effects of endosulfan and metapa in male rats, Ind. J. Exp. Biol., 16, 1000.

9) Dikshith, T. S. S. and Datta, K. K. (1978). Endosulfan: Lack of cytogenetic effects in male rats, Bull. Environ. Contam. Toxicol., 20, 826.

10) National Cancer Institute (1978). Bioassay of endosulfan for possible carcinogenecity, Technical Report, Series No. 62, USDHEW Publication No (NIH) 78-1312.

11) Gupta, P. K. and Gupta, R. C. (1979). Pharmacology, Toxicology and degradation of endosulfan, A review Toxicology, 13, 115.

12) Dikshith, T. S. S. and Raizada, R. B. (1981). Technical Report on Endosulfan to Excel Industries Ltd., India.

13) Dikshith, T. S. S. and Raizada, R. B. (1982). Technical Report on Endosulfan to National Chemical Laboratory, Pune, India.

14) Wootton, I. D. P. (1964). Microanalysis in Medical Biochemistry, 4th ed., Churchill Ltd., London.

15) Lowry, O. H., Rosenbrough, N. J., Farr, A. L. and Randall, R. J. (1951). Protein measurement with the folin phenol reagent, J. Biol. Chem., 193, 265.

16) Nelson, N. and Somogyi (1949). Determination of Glucose in Hawk's Physiological Chemistry (B. L. Oser. Ed.), McGraw Hill, New York, 1054.

17) Wintrobe, M. and Landsberg, J. W. (1935). A standard technique for the blood sedimentation test, Amer. J. Med. Sci., 189, 102.

18) Kolmer, K. A., Spaulding, E. H. and Robinson, H. W. (1951). Approved Laboratory Techniques, 5th ed., Scientific Book Agency, Calcutta, India.

19) Fisher, R. A. (1950). Statistical Methods for Research Workers, 11th ed., Oliver and Boyd Ltd., Edinburgh, UK.

20) Kushwah, H. S. (1978). Biochemical Studies on Endosulfan, Ph.D. Thesis, University of Indore, Indore, India.

21) Brown, V. K. (1980). Acute Toxicity in Theory and Practice, John Wiley \& Sons, New York.

22) Klaassen, C. D. and Doull, J. (1980). Evaluation of safety. Toxicological evaluation in: Toxicology, The Basic Science of Poisons, ed. by John Doull, C. D. Klaassen and M. O. Amdur.

23 ) Klaassen, C. D. (1980). Absorption, distribution and excretion of toxicants in: Toxicology The Basic Science of Poisons, ed. by John Doull, C. D. Klaassen and M. O. Amcü. 
304 T.S.S. DIKSHITH, R.B. RAIZADA, M.K. SRIVASTAVA AND B.S. KAPHALIA

24) National Research Council (1975). Endosulfan: Its effects on environmental quality, Technical report No. 14098, 100, Nat. Res. Council Canada.

25) World Health Organisation (1975). Data Sheet on Pesticides Endosulfan No. 15 $(V B C / 75.15)$. 